\title{
Endotoxin and Arachidonic Acid Metabolites in Portal, Hepatic and Arterial Blood of Cattle with Acute Ruminal Acidosis
}

\author{
By P. Haubro Andersen, M. Hesselholt and N. Jarløv \\ Department of Clinical Studies, Section of Surgery, Royal Veterinary and Agricultural University, Frederiks- \\ berg, Denmark
}

\begin{abstract}
Andersen, P. Haubro, M. Hesselholt and N. Jarløv: Endotoxin and arachidonic acid metabolites in portal, hepatic and arterial blood of cattle with acute ruminal acidosis. Acta vet.scand.1994, 35, 223-234. - Ruminal acidosis was induced experimentally with $70 \mathrm{~g}$ barley / $\mathrm{kg}$ body weight in 2 rumen fistulated cows with chronic indwelling catheters in the portal vein, in a hepatic vein and the carotid artery. The cows were followed for 24 and $20 \mathrm{~h}$ after the overfeeding and evaluated clinically and by clinical chemistry. The 2 cows exerted different responses to the treatment. Both cows showed signs of severe ruminal acidosis. Both cows had endotoxin in portal and hepatic vein blood, but only 1 of the cows convincingly developed a systemic endotoxaemia. A pre-hepatic release of the stable prostacyclin and thromboxane metabolites, 6-ketoprostaglandin $\mathrm{F}_{1 \alpha}$ and thromboxane $\mathrm{B}_{2}$ was demonstrated in this cow. The results of the present study show that endotoxin and arachidonic acid metabolites of pre-hepatic origin may be factors involved in the pathogenesis of ruminal acidosis, and that investigation of the factors affecting translocation of ruminal endotoxin and subsequent clearing in the liver, will be of importance.
\end{abstract}

Limulus amoebocyte lysate test; haematology; enzyme immunoassay; thromboxane $B_{2}$ 6-ketoprostaglandin $F_{1 \alpha}$; ruminitis; systemic inflammation; clearance; inflammation mediators; chronic catheterization.

\section{Introduction}

Ruminal acidosis is a frequent condition of high yielding dairy cows and may occur after ingestion of large amounts of readily digestible carbohydrates without a sufficient crude fiber level (Steg et al. 1988). The pathogenesis is still not fully understood. Attention has been focused on the ruminal formation of acidic or toxic microbial fermentation products and lately, the role of endotoxin has been discussed in particular (Andersen \& Jarløv 1990, Boosman et al. 1990, Aiumlamai et al. 1992). Large amounts of endotoxin is normally present in ruminal fluid of cattle and several authors have shown that the concentration of endotoxin increases when cattle are fed concentrate or grain instead of roughage (Nagaraja et al. 1978, Andersen et al. 1994a). However, controversy exists concerning a possible translocation of endotoxin from ruminal fluid to the blood in grain-engorged cows. Boosman et al. (1990) demonstrated, in 2 cows, a biphasic pattern of translocation, similar to the findings in carbohydrate overloaded horses (Sprouse et al. 1987) while others (Andersen \& Jarløv 1990) were unable to detect endotoxin in peripheral blood of cattle with experimentally induced ruminal acidosis, 
despite severe clinical signs of acute ruminal acidosis. The absence of systemic endotoxaemia was ascribed to rapid hepatic clearance of ruminal endotoxin from the portal blood, and the clinical signs were explained by a possible ill-effect of locally or systemically released inflammatory mediators. Intravenous administration of endotoxin to cattle elicits severe clinical symptoms even in minute amounts and induces liberation of several arachidonic acid metabolites and cytokines (Morris et al. 1986, Kenison et al. 1991, Jarløv et al. 1992).

The aim of the present study was therefore to examine the occurrence of endotoxin and arachidonic acid metabolites in portal blood, hepatic vein blood and arterial blood of grainengorged cows.

\section{Materials and methods \\ Animals}

Two adult Jersey cows (body weight 400 and $430 \mathrm{~kg}$ ) were ruminal fistulated and equipped with totally implanted indwelling catheters (Port-a-Cath, Pharmacia, Denmark) in the portal and hepatic veins and carotid artery according to the method described by Andersen et al. 1994b. The animals were allowed to recover for 6 weeks and was maintained on a daily diet consisting of $4.0 \mathrm{~kg}$ of a commercial concentrate mix (12\% crude protein, $68 \%$ barley) supplemented with $1 \mathrm{~kg}$ of hay. The cows are referred to as cow A and cow B.

\section{Experimental design}

During a $9 \mathrm{~h}$ control period, from -9 to $0 \mathrm{~h}$, baseline clinical parameters (rectal temperature, pulse and respiratory rates, $\mathrm{pH}$ (Portatest ${ }^{\circledR} 655 \mathrm{pH}$ meter, Knick, Germany), ruminal movements) were determined on a regular basis. Carotid artery blood samples for determination of clinical-chemical parameters (acid-base balance, packed cell volume
(PCV), leukocyte and thrombocyte counts, plasma lactate and zinc concentrations) were drawn every third hour. Portal vein, hepatic vein and carotid artery samples were drawn every hour for determination of endotoxin concentration and every third hour for determination of thromboxane $\mathrm{B}_{2}$ (TXB) and 6ketoprostaglandin $\mathrm{F}_{1 \alpha}$ (6-keto-PGF) concentrations.

After the control period, ruminal acidosis was induced at time 0 by feeding $70 \mathrm{~g} / \mathrm{kg}$ body weight of ground barley (Dougherty et al. 1975). The cows were allowed to eat voluntarily, the remainder was administered through the rumen fistula after they stopped eating. Clinical monitoring and sampling of blood were continued until the death of the animal. The catheters were kept patent during the experiment by slow infusion of sterile, pyrogen free saline water ( 20 drops / min). The animals were treated with pethidine, $2 \mathrm{mg} / \mathrm{kg}$ body weight once every $6 \mathrm{~h}$, in order to minimize discomfort. Cow A was euthanized after 24h, cow B died suddenly after $20 \mathrm{~h}$. Autopsy was performed within few hours for both animals.

\section{Limulus Amoebocyte Lysate (LAL) assay}

Blood samples for endotoxin analysis were drawn in sterile pyrogen free $5 \mathrm{ml}$ syringes under sterile precautions. The samples were stabilized with 50 i.u. of pyrogen free heparin (DAK, Denmark, 100,000 iu/l) and centrifuged immediately. After dilution with sterile and pyrogen free water (Atlas ${ }^{\circledR}$, Sussex, UK) and heat extraction for $5 \mathrm{~min}$ at $75^{\circ} \mathrm{C}$, the samples were stored at below $-20^{\circ} \mathrm{C}$ until testing. The LAL assay was performed as a tube test in accordance with the directions of the manufacturer (Pyrotell ${ }^{\circledR}$ lot 99-75-418, Associates of Cape Cod, USA). It was combined with the rocket immunoelectrophoresis as described earlier (Andersen \& Jarl $\varnothing v$ 1990). Electrophoresis was run with $6.5 \cdot 10^{-6} 1$ anti-coagulogen 
(DakoPatts, code 0886, Denmark) in the whole gel at $10 \mathrm{~V} / \mathrm{cm}$ for at least $5 \mathrm{~h}$. The mean of 2 replicates of each sample was compared to a control endotoxin (Escherichia coli control standard endotoxin (code \#O113, PPE-E-434), Associates of Cape Cod, USA) standard curve. The sensitivity of this method was determined to be 30 endotoxin units (EU) / 1 in our laboratory. Glassware and other supplies were either of a commercial non-pyrogenic type or depyrogenized in dry heat at $250^{\circ} \mathrm{C}$ for at least $6 \mathrm{~h}$.

\section{$T X B$ and 6-keto-PGF assays}

Blood samples were collected in $5 \mathrm{ml}$ syringes containing $0.5 \mathrm{ml}$ of a mixture of $95 \%$ of a $2 \%$ EDTA solution and $5 \%$ of a $0.04 \mathrm{~mol} / 1$ indomethacin solution in order to prevent spontaneous metabolism of arachidonic acid to prostaglandins. A few ml of blood was drawn from the catheters before collection of the sample. The plasma samples were centrifuged immediately after collection and stored at below $-20^{\circ} \mathrm{C}$.

Solid phase extraction of the plasma samples was performed using SepPak C18 (Waters, Technunc, Denmark) columns prior to analysis for TXB and 6-keto-PGF, in order to avoid interference with non-esterified fatty acids (Powell 1980).

Measurement of the stable metabolite $\mathrm{TXB}_{2}$ is accepted as an estimate of the level of systemically formed thromboxane $\mathrm{A}_{2}$ (Granström et al. 1976). Thromboxane $A_{2}$ is unstable and inevitably formed during the sampling procedure. TXB was measured using a commercial enzymeimmunoassay kit (Biotrak RPN 220, Amersham, UK). The principle of the immunoassay is based on the competition between unlabelled TXB from the sample and a fixed quantity of peroxidase labelled TXB for a limited number of binding sites on a TXB specific antibody. The amount of peroxidase labelled ligand bound by the antibody will then be inversely proportional to the TXB concentration of the added ligand (sample), which can be determined by interpolation from a standard curve. The assay was performed as described by the manufacturer. Measurement of the stable metabolite 6-ketoPGF is accepted as a measure of prostacyclin (prostaglandin $\mathrm{I}_{2}$ ), which is unstable (Demers \& Derck 1980). A commercial enzymeimmunoassay kit (Biotrak RPN 221, Amersham, $\mathrm{UK}$ ), following the same principles as described for measurement of TXB, was used for determination of 6-keto-PGF.

\section{Clinical-chemical blood analysis}

Thrombocyte counts were done by phase contrast microscopy and an automatic acid-base laboratory (ABL4, Radiometer, Denmark) was used for determination of acid-base balance. Leukocyte counts, PCV and determination of plasma concentrations of zinc and lactate were performed according to routine clinical-chemical methods.

\section{Results \\ Clinical data}

Rumen motility and $\mathrm{pH}$ was significantly decreased and pulse and respiratory rates were elevated 4 to $5 \mathrm{~h}$ (data not shown) after the experimental overfeeding. Rumen $\mathrm{pH}$ decreased continuously and reached a minimum of 4.09 and 3.80 at 22 and $16 \mathrm{~h}$ in cow A and B, respectively. Both cows developed diarrhoea and signs of dehydration and shock (increased PCV, lactaemia and metabolic acidosis). Fever was observed after 3 and $9 \mathrm{~h}$, and lasted during the rest of the experiment, peaking 18 and $15 \mathrm{~h}$ in cow A and cow B, respectively (Figs. 1 and 2). The cows became recumbent and depressed after 10 - 12h. Cow B died suddenly after $20 \mathrm{~h}$, while cow A was euthanized at $24 \mathrm{~h}$. At autopsy the placement of the cath- 


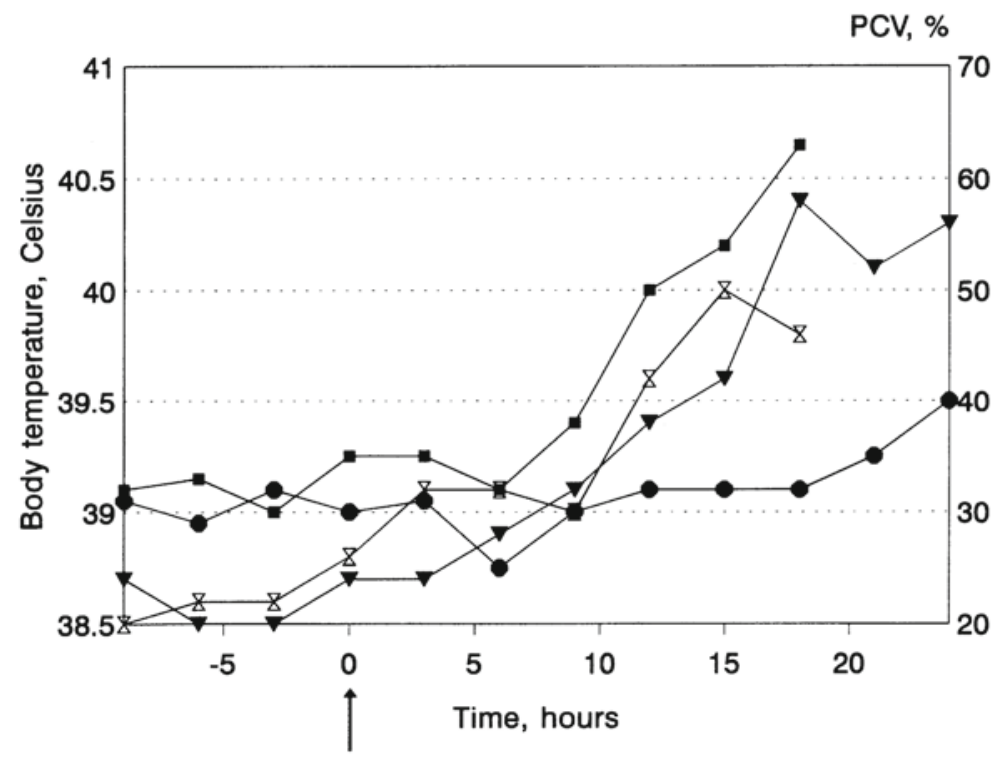

Figure 1. Body temperature cow A $\mathbf{\nabla}$ and cow B 8 . Packed Cell Volume (PCV) cow A $\bullet$ and cow B $\mathbf{\square}$. The arrow indicates time for induction of ruminal acidosis.

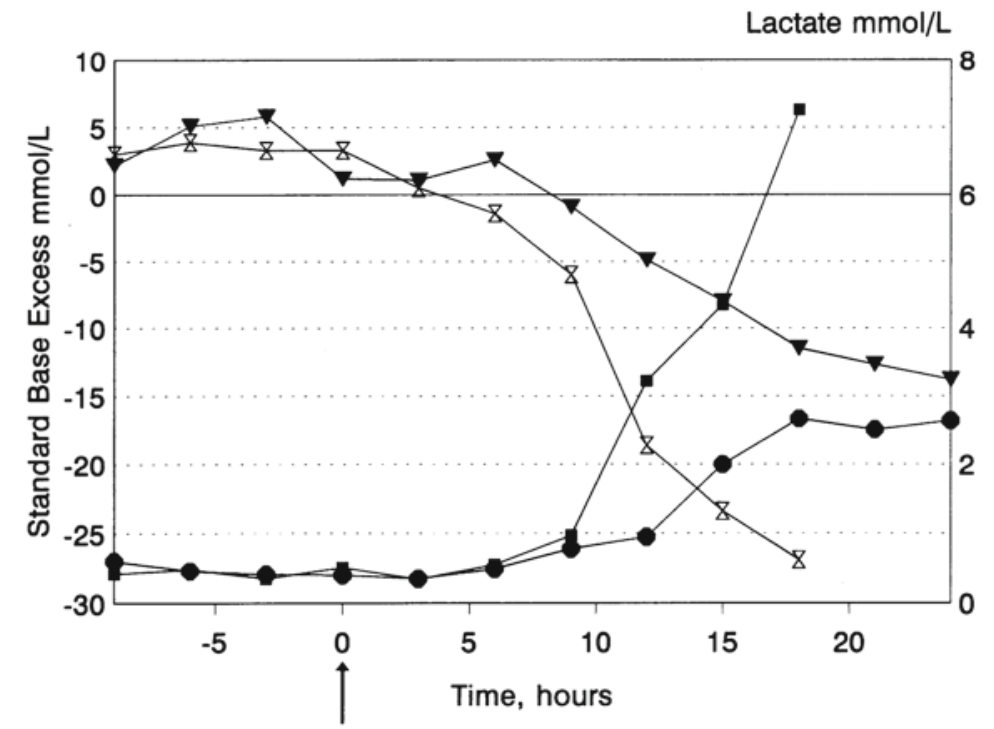

Figure 2. Standard Base Excess (SBE) for cow A $\boldsymbol{\nabla}$ and cow B 8 . Plasma lactate concentrations cow A and cow $B$. The arrow indicates time for induction of ruminal acidosis. 


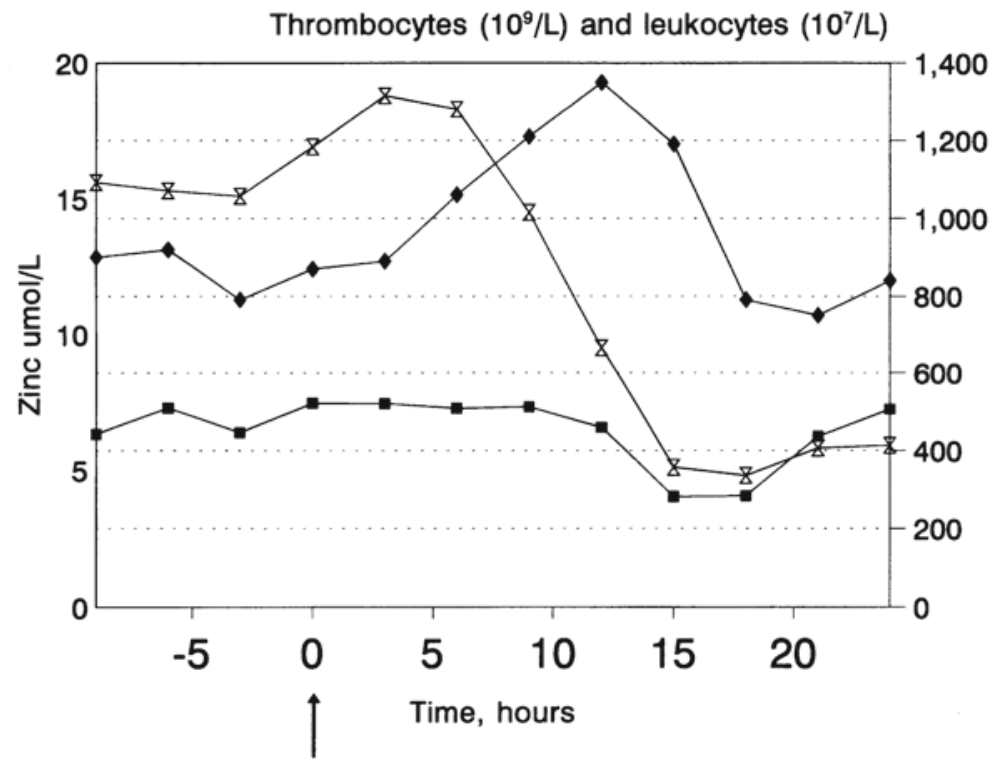

Figure 3. Cow A: Leukocyte and thrombocyte counts; plasma zinc concentration $\nabla$. The arrow indicates time of induction of ruminal acidosis.

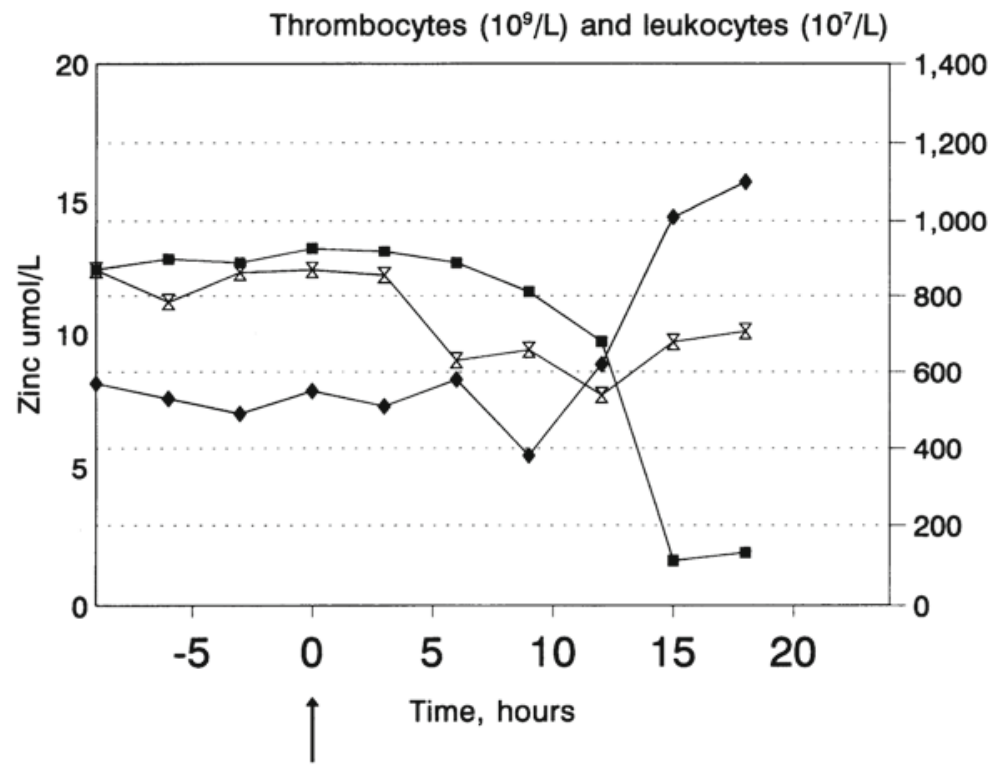

Figure 4. Cow B: Leukocyte and thrombocyte counts; plasma zinc concentration $\nabla$. The arrow indicates time of induction of ruminal acidosis. 


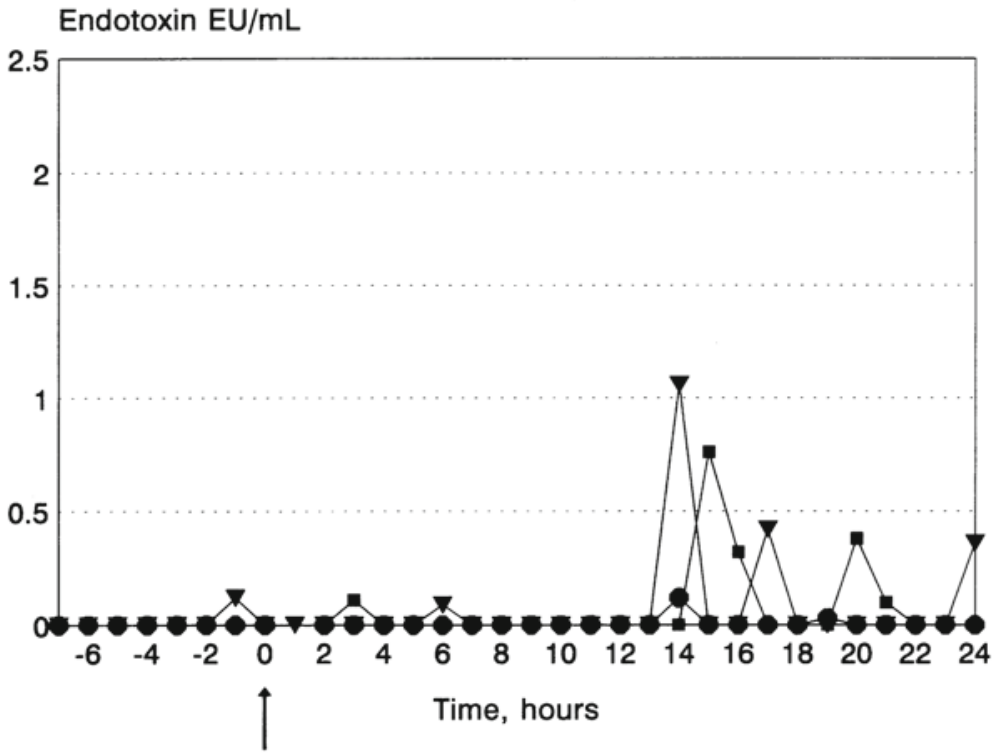

Figure 5. Cow A: Endotoxin concentrations in portal blood $\mathbf{\nabla}$, hepatic blood $\mathbf{\square}$ and arterial $\bullet$ blood. The arrow indicates time of induction of ruminal acidosis.

\section{Endotoxin $\mathrm{EU} / \mathrm{mL}$}

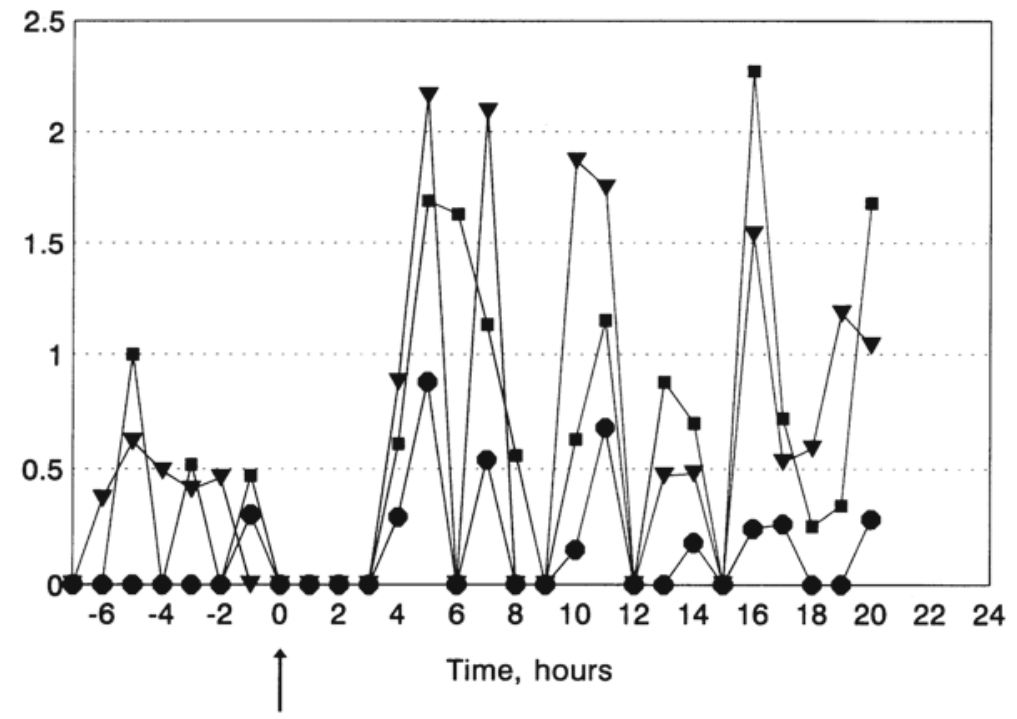

Figure 6. Cow B: Endotoxin concentrations in portal blood $\boldsymbol{\nabla}$, hepatic blood $\boldsymbol{\square}$ and arterial $\bullet$ blood. The arrow indicates time of induction of ruminal acidosis. 


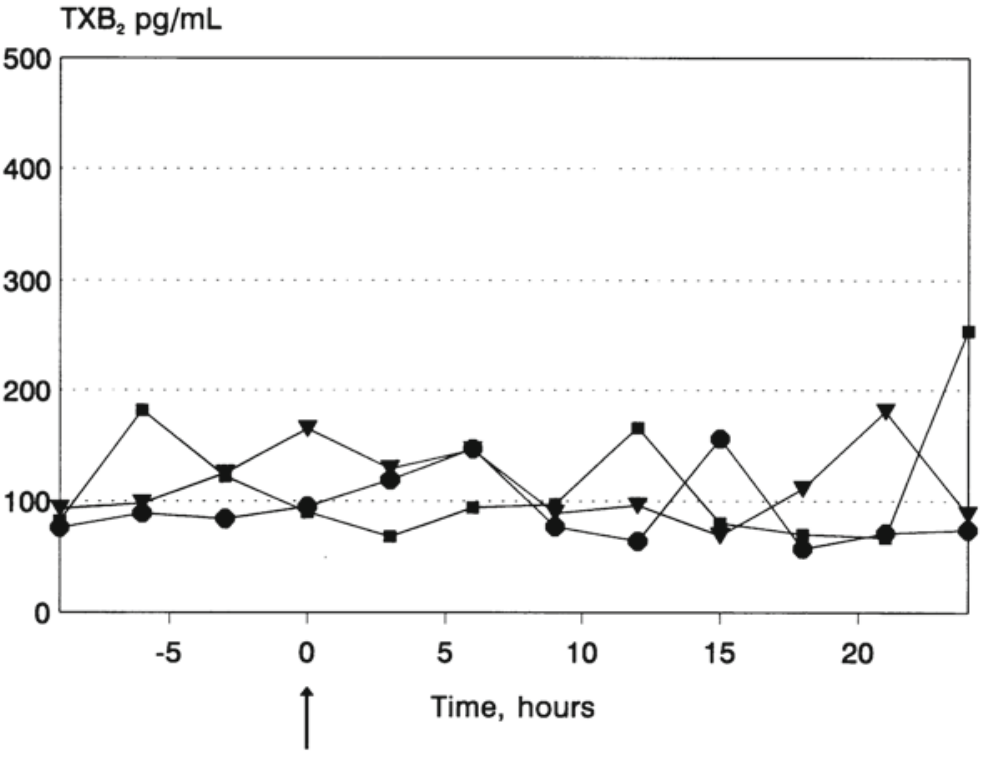

Figure 7. Cow A: Concentrations of the stable thromboxane metabolite thromboxane $\mathrm{B}_{2}\left(\mathrm{TXB}_{2}\right)$ in portal blood $\boldsymbol{\nabla}$, hepatic blood $\boldsymbol{\square}$ and arterial $\bullet$ blood. The arrow indicates time of induction of ruminal acidosis.

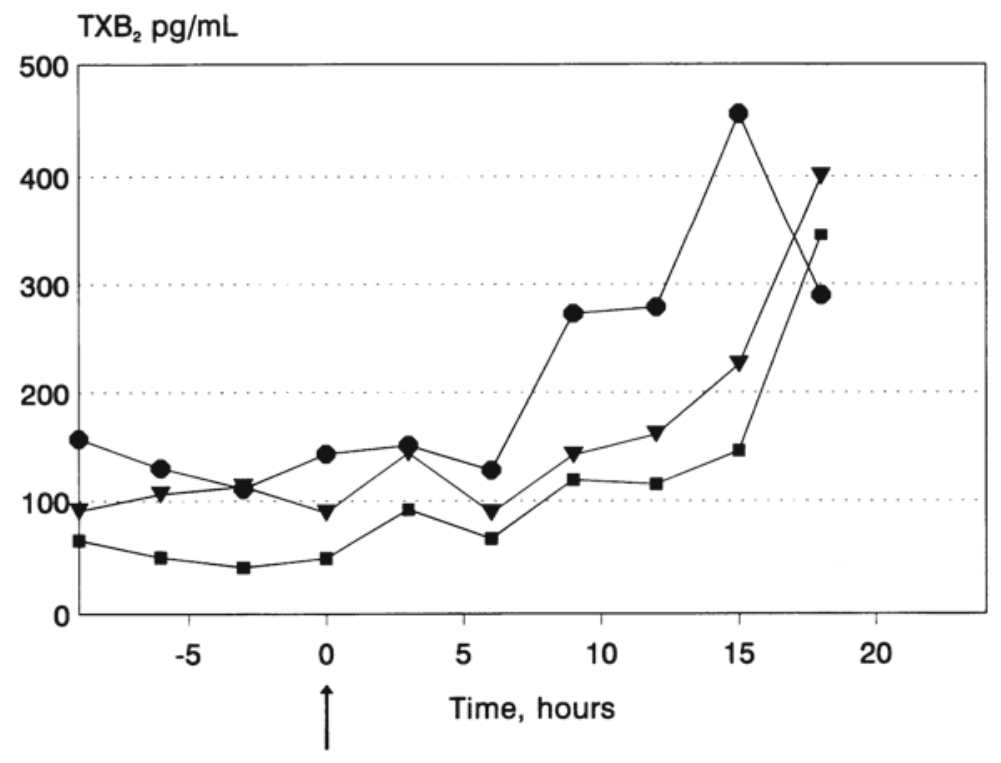

Figure 8. Cow B: Concentrations of the stable thromboxane metabolite thromboxane $\mathrm{B}_{2}\left(\mathrm{TXB}_{2}\right)$ in portal blood $\boldsymbol{\nabla}$, hepatic blood $\mathbf{\square}$ and arterial $\bullet$ blood. The arrow indicates time of induction of ruminal acidosis. 


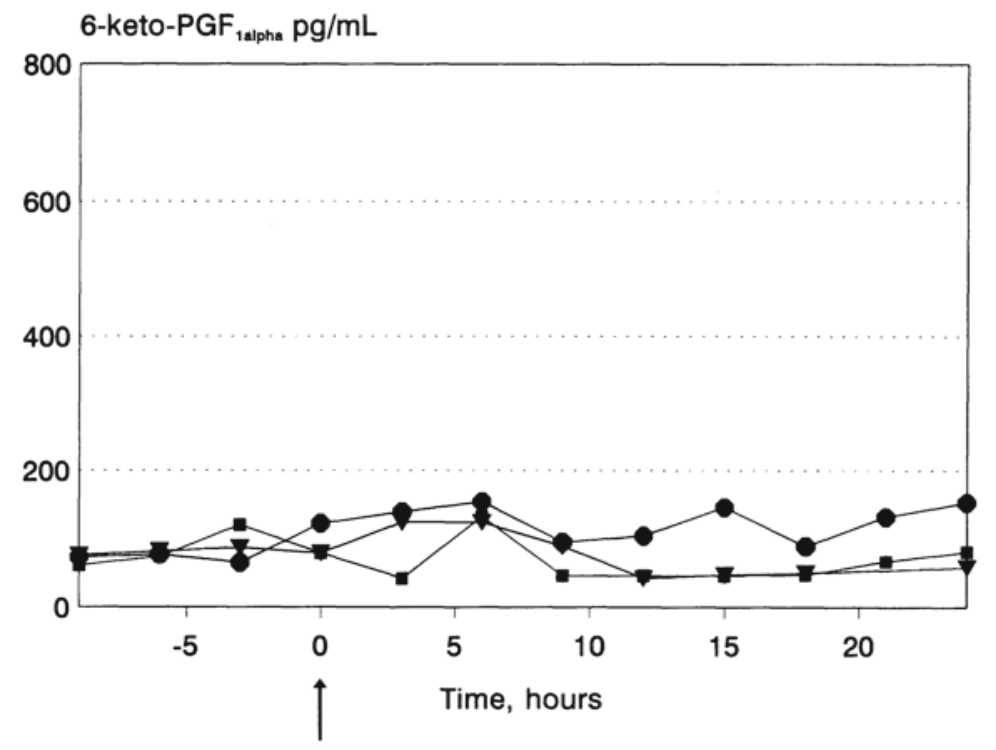

Figure 9. Cow A: Concentrations of the stable prostacycline metabolite 6-keto-prostaglandin $\mathrm{F}_{1 \alpha}$ (6-ketoPGF) in portal blood $\boldsymbol{\nabla}$, hepatic blood $\boldsymbol{\square}$ and arterial $\bullet$ blood. The arrow indicates time of induction of ruminal acidosis.

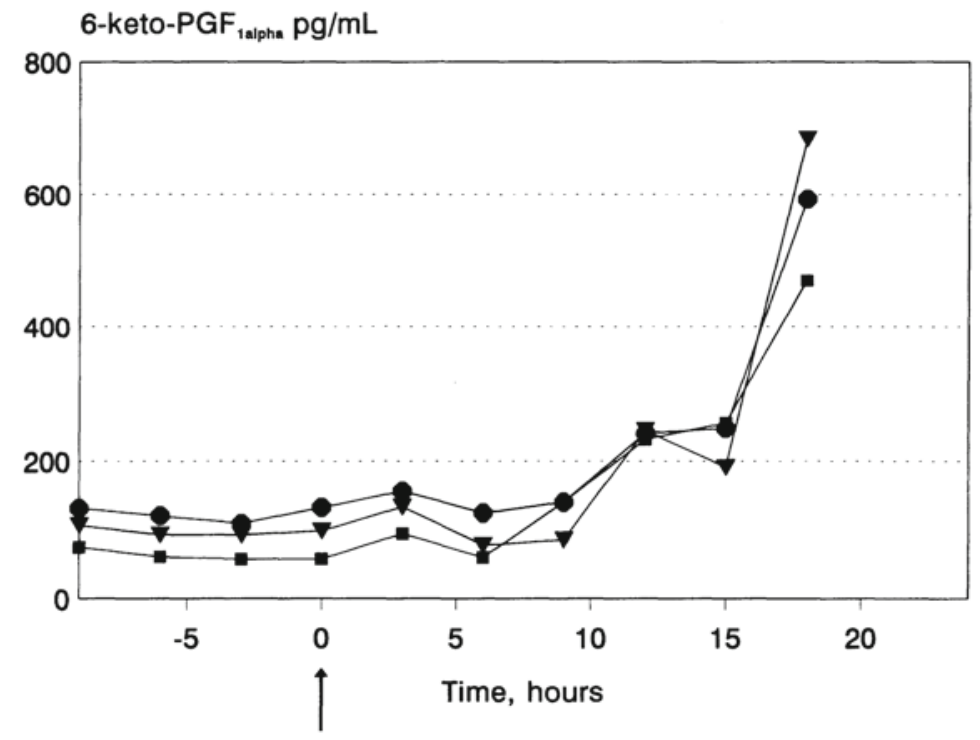

Figure 10. Cow B: Concentrations of the stable prostacycline metabolite 6-keto-prostaglandin $\mathrm{F}_{1 \alpha}$ (6-ketoPGF) in portal blood $\boldsymbol{\nabla}$, hepatic blood $\boldsymbol{\square}$ and arterial $\bullet$ blood. The arrow indicates time of induction of ruminal acidosis. 
eters was verified. Significant gross lesions were acute inflammation of the ruminal wall, with areas of de-epithelialization. There were no signs of disseminated intravascular coagulopathy or laminitis.

\section{Haematological data}

The leukocyte and thrombocyte counts showed marked variations. Cow A developed a significant leukocytosis, starting at $6 \mathrm{~h}$ after overfeeding. The leukocyte count peaked a $12 \mathrm{~h}$ and dropped below the baseline value at $20 \mathrm{~h}$. At $12 \mathrm{~h}$ a moderate thrombocytopenia developed (Fig. 3). Cow B developed an initial leukopenia at $9 \mathrm{~h}$, which was changed into leukocytosis at $15 \mathrm{~h}$. A thrombocytopenia was manifest at $12 \mathrm{~h}$ and was severe at $15 \mathrm{~h}$ (Fig. 4). Cow A showed a marked hypozincaemia after 9h (Fig. 3), while cow B showed only minor and transient decreases in plasma zinc concentrations (Fig. 4).

\section{Endotoxin determinations}

The endotoxin data for cow A and cow B are given in Figs. 5 and 6, respectively. Endotoxin could not be detected in the arterial blood of the cows during the pre-experimental period, except at $-1 \mathrm{~h}$, where cow B was slightly LAL positive. During the pre-experimental period, LAL was frequently positive in the portal and hepatic blood samples, most marked for cow B. Starting $12 \mathrm{~h}$ after overfeeding, portal and hepatic samples of cow A frequently contained relatively low concentrations of endotoxin and only 1 arterial blood sample was convincingly positive at $14 \mathrm{~h}$. In cow B, arterial blood samples became positive $4 \mathrm{~h}$ after the overfeeding, and 8 samples contained relatively low amounts of endotoxin. Hepatic and portal blood samples had 2 - 4 times higher concentrations of endotoxin during that period. Endotoxin concentrations fluctuated in both cows, and no pattern was obvious.

\section{$T X B$ and 6-keto-PGF determinations}

Cow A showed no considerable elevations of TXB or 6-keto-PGF (Figs. 7 and 9). Cow B showed increased concentration of TXB $9 \mathrm{~h}$ after the overfeeding and of 6-keto-PGF after 12h (Figs. 8 and 10). Both trends continued until the death of the animals.

\section{Discussion}

Experimental overfeeding with $70 \mathrm{~g}$ barley / $\mathrm{kg}$ body weight caused a severe degree of ruminal acidosis, as defined by Dirksen (1970). Prior to the experiment, the cows were maintained on a high concentrate ration in order to achieve a large increase of endotoxin of the ruminal content (Andersen et al. 1994a). Despite these 2 factors, only 1 of the cows (B) convincingly showed systemic endotoxaemia. The 2 cows exerted a widely different response to the treatment, regarding the relative severity of clinical signs and clinicalchemical observations (Figs. 1 - 4), occurrence of systemic and localized endotoxaemia (Figs. 5 and 6) and of TXB and 6-keto-PGF generetaion (Figs. 7 - 10). While cow A showed only occasional endotoxaemia, cow B suffered from frequent and high degrees of both systemic and localized (portal and hepatic vein) endotoxaemia. Both cows showed leukocytosis, but cow B had a preceding period of leukopenia and developed faster and more profound thrombocytopenia (Figs. 3 and 4). These haematological changes are endotoxin dose-dependent and the finding corresponds well to the finding of an apparently larger endotoxin load in cow B (Lohuis et al. 1988). This was not the case of the changes in zinc concentration. A decline in plasma zinc and iron is thought to reflect a beneficial acute phase response accompanying infection and fever. However, the most pronounced decrease in zinc concentration was observed in cow A, while cow B showed a considerably 
lower and transient degree of hypozincaemia (Figs. 3 and 4). A similar curious case was reported by Groothuis et al. (1981), who observed that 1 out of 8 calves, experimentally infected with Salmonella dublin failed to respond with hypozincaemia. This calf was in poor clinical condition and failed to recover, as cow B. The mecanism for this failure to produce an adequate response remains unclear and needs further investigation.

This study demonstrates that local episodes of portal and hepatic vein endotoxaemia are much more frequent than the systemic endotoxaemia. Endotoxin is a common contaminant of portal blood, even in healthy individuals (Prytz et al. 1976, Andersen 1985). This is observed in the control period of cow B. Feeding of a high concentrate ration prior to the experiment may have caused some epithelial damage due to rumenitis in cow $\mathrm{B}$, which was present before the experiment. Inflammation of the ruminal wall may cause liberation of inflammation mediators, including TXB and 6-keto-PGF, as well as translocation of ruminal endotoxin to the portal blood. The present, limited study shows that elevated concentrations of arachidonic acid metabolites TXB and 6-keto-PGF (Figs. 6, 8 and 10) are related to the occurrence of systemic endotoxaemia. The elevated concentrations of TXB and 6-keto-PGF in the portal blood of cow $\mathrm{B}$ demonstrates that a pre-hepatic release of mediators may take place in grain-engorged cattle. This observation is in accordance with observations of horses with experimental colonic volvulus (Stick et al. 1992).

It is commonly accepted that endotoxin escaping the gastro-intestinal tract is detoxified mainly by the liver and the lungs (Mori et al. 1973). This study finds, however, frequent and high concentrations of endotoxins in the hepatic vein blood, most pronounced in cow B. Endotoxin occurs in the arterial blood simul- taneously with or delayed from much higher concentrations of endotoxin in the hepatic and portal blood (Figs. 5 and 6). If this is an effect of dilution of the hepatic vein blood into the systemic blood pool or a result of further detoxification by the lungs, is not clear. During the course of the experiment, concentrations of TXB and 6-keto-PGF were generally lower in hepatic blood than in portal blood in cow B, suggesting an apparent clearing of these eicosanoids or their metabolites in the liver. The corresponding systemic concentrations, however, tended to be generally higher, an observation which cannot be explained without further investigation.

There has been considerable controversy concerning the role of endotoxin for the development of the systemic signs of ruminal acidosis. Some authors have reported the presence of endotoxin in jugular blood of cattle with experimental ruminal acidosis (Dougherty et al. 1975, Boosman et al. 1990), while others were unable to detect systemic endotoxaemia ( $A n$ dersen \& Jarløv 1990). Aiumlamai et al. (1992) detected endotoxins in jugular blood of 3 out of 4 identical cases of induced ruminal acidosis. The design of the present study, including investigation of portal and hepatic vein blood and frequent sampling, provides high reliability concerning interpretation of single positive samples, which always should be suspected as false positives (e.g. the positive arterial sample at $-1 \mathrm{~h}$ in cow B, Fig. 6). Furthermore, this study may yield, at least in part, an explanation of the different observations made by various authors concerning presence or absence of systemic endotoxaemia in ruminal acidosis. The length of the interval between blood sampling seems to be very important, since this detailed study shows that the translocation of endotoxin seems unpredictable and intermittent. Other studies used sampling times varying from 2 to $10 \mathrm{~h}$ (Dougherty et al. 
1975, Boosman et al. 1990, Aiumlamai et al. 1992). Cow A showed systemic endotoxaemia only once during the experiment, and the chance of detecting systemic endotoxaemia in this serious case of ruminal acidosis would have been lower, if sampling intervals had been longer. The present experiment confirms observations made by others, that cows do not respond uniformly to experimental overfeeding, making a dose-response relationship difficult to establish (Dougherty et al. 1975, Andersen 1985, Andersen et al. 1990, Aiumlamai et al. 1992). It seems, that some cows develop systemic endotoxaemia during ruminal acidosis, while others avoid it. The reason for this apparent resistance is interesting and further research is needed. The detoxification capacity of the liver, and factors affecting it, as well as immunological and metabolic factors, will be of importance.

\section{Acknowledgements}

This study is supported by grants from the Danish Agricultural and Veterinary Research Council (134216-1).

\section{References}

Aiumlamai S, Kindahl H, Fredriksson $G$, Edqvist L$E$, Kulander L, Eriksson $O$ : The role of endotoxins in induced ruminal acidosis in calves. Acta vet.scand. 1992, 33, 117 - 127.

Andersen PH: Portal endotoxaemia in cattle - an experimental investigation. Ph.D. thesis, Royal Veterinary and Agricultural University, Copenhagen, Denmark. 1985, p. 69 - 73.

Andersen PH, Bergelin B, Christensen KA: Effect of the feeding Regimen on the concentration of free endotoxin in ruminal fluid of cattle. J.Anim. Sci. 1994a, 72, 487 - 491.

Andersen PH, Jarløv N, Basse A: Chronic Catheterization of the Portal Vein, a Mesenteric vein and an Hepatic vein in Cattle Using a Totally Implantable Catheter System. Submitted 1994b.

Andersen PH, Jarl $\vee v$ : Investigation of the possible role of endotoxin, TXA2, PGI2 and PGE2 in experimentally induced rumen acidosis in cattle. Acta vet.scand. 1990, 31, 27 - 38.

Boosman R, Mutsaers CWAAM, Klarenbeek A: Experimental bovine ruminal acidosis associated with endotoxaemia and laminitis. Bovine Laminitis. Histopathologic and arteriographic aspects and its relation to endotoxaemia. Thesis, University of Utrecht, The Netherlands. 1990, p. $78-93$.

Demers $L M$, Derck DD: A radioimmunoassay for 6keto- prostaglandin $\mathrm{F}_{1 \alpha}$. Advances in Prostaglandin and Thromboxane Research, Raven Press New York 1980, 7, p. 193-199.

Dirksen G: Acidosis. Physiology and Metabolism in the Ruminant. A.T. Phillipson 1970, p. 612 - 629.

Dougherty RW, Coburn KS, Cook HM, Allison M: A preliminary study of the appearance of endotoxin in the circulatory system of sheep and cattle after induced grain-engorgement. Amer. J. vet. Res. $1975,36,831$ - 832.

Granström E, Kindahl H, Samuelsson B: Radioimmunoassay for thromboxane $B_{2}$. Analyt.Letters 1976, 9, 611 - 627.

Groothuis DG, van Miert ASJPAM, Schotman AJH: Zinc concentration in plasma during experimental Salmonella dublin infection and endotoxin induced fever in calves. Vet. Rec. 1981, 109, 176 177.

Jarløv N, Andersen PH, Hesselholt M: Pathophysiology of experimental bovine endotoxicosis: Endotoxin induced synthesis of prostaglandins and thromboxane and the modulatory effect of some non-steroidal anti-inflammatory drugs. Acta vet.scand. 1992, 33, 1 - 8.

Kenison DC, Elsasser TH, Fayer R: Tumor necrosis factor as a potential mediator of acute metabolic and hormonal responses to endotoxemia in calves. Amer.J.vet.Res. 1991, 52, 1320-1326.

Lohuis JACM, Verheijden JHM, Burvenich C, van Miert ASJPAM: Pathophysiological effects of endotoxin in ruminants. Vet. Quart. 1988, 10, 117 -125 .

Mori K, Matsumoto K, Gans $H$ : On the in vivo clearance and detoxification of endotoxin by lung and liver. Ann.Surg. 1973, 177, 159 - 163.

Morris DD, Cullor JS, Whitlock RH, Wickstrom M, Corbeil LB: Endotoxemia in neonatal calves given antiserum to a mutant Escherichia coli (J-5). Amer.J.vet.Res. 1986, 47, 2554 - 2565.

Nagaraja TG, Bartley EE, Fina LR, Anthony HD, Dennis SM, Bechtle RM: Quantitation of endo- 
toxin in cell-free rumen fluid of cattle. J.Anim.Sci. 1978, 46, 1759 - 1966.

Powell WS: Rapid extraction of oxygenated metabolites of arachidonic acid from biological samples using octadecylsilyl silica. Prostaglandins 1980, 20, 947 - 957.

Prytz H, Holst-Christensen J, Korner B, Liehr H: Venous and systemic endotoxamia in patients without liver disease and systemic endotoxaemia in patients with cirrhosis. Scand.J.Gastroenterol. 1976, 11, 857 - 863.

Sprouse RF, Garner HE, Green EM: Plasma endotoxin levels in horses subjected to carbohydrate induced laminitis. Equine vet. J. 1987, 19, 25 - 28.

Steg A, van der Honing $Y$, de Visser $H$ : Effect of fibre in compound feeds on the performance of ruminants. In: Haresign DJ (ed.): Recent Developments in Ruminant Nutrition. Butterworth 1988, (2. ed.), p. 142 - 158.

Stick JA, Arden WA, Robinson RA, Shobe EM, Roth $R A$ : Thromboxane and prostacyclin production in ponies with colonic volvulus. Am.J.Vet.Res. 1992, 53, $563-568$.

\begin{abstract}
Sammendrag
Unders $\emptyset$ gelse af endotoksin og arakidonsyre metabolitter $i$ blod fra v. portae, v. hepatica og a. carotis ved eksperimentelt induceret vomacidose hos kvag.
\end{abstract}

To vom-fistulerede køer med permanente katetre i v. portae, en v. hepatica samt a. carotis blev eksperimentelt påført vomacidose $\mathrm{i}$ alvorlig grad ved intraruminal indgift af $70 \mathrm{~g}$ byg $/ \mathrm{kg}$ legemsvægt. De to køer blev observeret klinisk og klinisk-kemisk i hhv. 24 og 20 timer efter induktionen. Køernes respons på vomacidosen var forskelligt. Begge køer havde endotoksin i blod fra v. portae og v. hepatica, men kun den ene udviklede en systemisk endotoksæmi. Der blev i denne ko påvist en præ-hepatisk frigørelse af de stabile prostacyklin og tromboxan metabolitter 6-keto-prostaglandin $\mathrm{F}_{1 \alpha}$ og tromboxan B2.

Undersøgelsen konkluderer, at endotoksin og præhepatisk frisatte arakidonsyre metabolitter er involveret $i$ udviklingen af vomacidose, og at en belysning af de faktorer, der påvirker translokation af vomendotoksin til portal gebetet og leverens detoksifikationsevne, vil være nødvendig.

(Received January 27, 1994; accepted April 14, 1994).

Reprints may be requested from: P. Haubro Andersen, Department of Clinical Studies, Section of Surgery, Royal Veterinary and Agricultural University, Bülowsvej 13, DK-1870 Frederiksberg C, Denmark. 